ERIA-DP - 2013-03

ERIA Discussion Paper Series

\title{
ASEAN Regional Cooperation on Competition Policy
}

\author{
Cassey LEE \\ University of Wollongong, Australia \\ Yoshifumi FUKUNAGA \\ Economic Research Institute for ASEAN and East Asia
}

April 2013

\begin{abstract}
ASEAN member states (AMSs) intend to establish the ASEAN Community by 2015. A key component of this goal is the formation of the ASEAN Economic Community (AEC). The AEC Blueprint was initiated to facilitate and monitor the implementation of the AEC during the period 2008-2015. Competition policy will play an important role in the achievement of the AEC. There has been significant progress in regional cooperation to achieve the competition policy targets listed in the AEC Blueprint. Even though only half of AMSs have implemented competition laws, regional cooperation in this area has been fairly strong. The main emphasis has been on publishing regional guidelines and a handbook on competition policy in ASEAN as well as capacity building activities. There needs to be a renewed impetus to implement national competition laws in AMSs that have not done so. There also remain significant opportunities for enforcement cooperation and pooling of resources for capacity building in competition policy in the region.
\end{abstract}

Keywords: Competition Policy, Competition Law, ASEAN, Regional Integration, ASEAN Economic Community, AEC Blueprint

JEL Classification:F15, L40, L50 


\section{Introduction}

Regional cooperation amongst the ASEAN member states (AMSs) in recent years has been driven by their intention to establish the ASEAN Community by the year 2015. First announced in 2003, the ASEAN Community is to be underpinned by three main pillars, namely the ASEAN Economic Community (AEC), the ASEAN Security Community and the ASEAN Socio-Cultural Community. ${ }^{1}$ The achievement of the AEC entails regional integration of the economies of the AMSs.

A key initiative to advance the implementation of the AEC has been the $A E C$ Blueprint which was first announced in 2006 and adopted in 2007. In the AEC Blueprint, the AEC will be advanced by:

\footnotetext{
“identifying the characteristics and elements of the AEC by 2015 consistent with the Bali Concord II with clear targets and timelines for implementation of various measures as well as pre-agreed flexibilities to accommodate the interests of all ASEAN Member Countries” (ASEAN, 2008, p.5).
}

The list of key characteristics and elements of the AEC includes: (i) a single market and production base, (ii) a highly competitive economic region, (iii) a region of equitable economic development, and (iv) a region fully integrated into the global economy. In the Blueprint, competition policy has been identified as a key area of emphasis to achieve "a highly competitive economic region". ${ }^{2}$ In this regard, a number of "priority actions” were identified and scheduled to be implemented during the period 2008-2015. 
The main purpose of this study is to provide a review of ASEAN regional cooperation on competition policy in terms of the implementation of the priority actions identified in the AEC Blueprint. Aside from assessing the degree, efficacy and impact of implementation of the priority actions, this study will provide an analysis of the remaining gaps in implementation as well as policy recommendations to address these gaps in the future. ${ }^{3}$

The rest of the paper is structured as follows. Section 2 provides a discussion of the role of competition policy in the AEC. Section 3 focuses on the implementation and enforcement of competition law in ASEAN countries. Section 4 provides an assessment of competition policy and regional cooperation in the AEC Blueprint. Section 5 concludes the report by summarizing the key findings and by providing some policy recommendations.

\section{Competition Policy in the ASEAN Economic Community}

Competition is clearly an important aspect of ASEAN's vision of regional economic integration. It is integral to all four characteristics of the AEC. The formation of a single market and production base is premised upon the notion of competition across markets in the ASEAN countries. The economic competitiveness of the ASEAN region and its integration into the global economy requires that its

member countries are able to compete globally. ${ }^{4}$ Competition also ensures that the benefits from regional integration are equitably distributed between and amongst consumers and producers in the region as well as amongst ASEAN-member 
countries. In this regard, competition policy, defined as any governmental policy that promotes competition in markets, is an important policy in the realization of the AEC.

\section{(a) The ASEAN Economic Community}

ASEAN countries have articulated their vision of regional economic integration in terms of the concept and goal of the AEC. The key characteristics of the AEC have been formally identified as: ${ }^{5}$

- a single market and production base

- a highly competitive economic region

- a region of equitable economic development, and

- a region fully integrated into the global economy.

In the above characterization of the AEC, both internal and external aspects of regional integration are important. The creation of a single market and production base is to be achieved via the "four freedoms" in the cross-border movement of goods, services, capital and labour (internally) within the ASEAN region (Lloyd, 2005 and Wattanapruttipaisan, 2006). ${ }^{6}$ In addition, this is augmented by the presence of institutions and policies relating to competition, consumer protection, intellectual property rights and infrastructure development that would further reduce internal within-border (or beyond the border) frictions.

The economies of AMSs are generally open to trade and investment. The development strategies of many AMSs have entailed export-oriented industrialization driven by foreign direct investment (FDI). Thus, the external dimensions of the AEC are important. They are aimed at enhancing the 
attractiveness of the region as a whole to FDI as well as ensuring that the region remains embedded within the global production network.

The AEC also recognizes that the level of development amongst ASEAN countries is currently uneven. It includes some emphasis on the development of small and medium enterprises (SMEs) as well as capacity-building activities that are needed to address this problem.

\section{(b) Competition Policy and the Achievement of the AEC}

Even though competition policy is placed as a priority area under the objective of achieving a competitive economic region, its role and importance clearly goes beyond this. This is implied in the definition of competition policy in the ASEAN Regional Guidelines on Competition Policy: ${ }^{7}$

"Competition policy can be broadly defined as a governmental policy that promotes or maintains the level of competition in markets, and includes governmental measures that directly affect the behaviour of enterprises and the structure of industry and markets.”

The above broad definition of competition policy suggests that some of the policies that enhance the "four freedoms" such as trade (goods and services) and market liberalization can be considered to be competition policies in so far as they enhance the degree of competition in markets. If one adopts this view, competition policies have been implemented in many ASEAN countries long before national competition laws were enacted in many of these countries. Such policies have sometimes been also construed as part of a country’s industrial policy. 
Industrial policy has been defined as government policy aimed at supporting specific firms or/and sectors in such a way as to bring about structural changes in the economy. ${ }^{8}$ When such policies involve the reduction of import tariffs and non-tariff barriers, they clearly have pro-competition effects. Thus, such policy initiatives undertaken to achieve the AEC can be considered to be competition policies. In general, the achievement of the AEC is likely to also require the reduction or scaling back of industrial policies that lessen competition such as industrial policies aimed at supporting infant industry or national champions via import restrictions and entry barriers (e.g. restrictions via licensing).

\section{(c) Competition Policy, Competition Law and the AEC}

Competition policy includes but is not restricted to competition law. Competition law is one component (albeit a very important one) of competition policy. National competition laws are legislations that "support competition by prohibiting anti-competitive agreements, abuse of dominant position, anti competitive mergers and other restrictive trade practices” (ASEAN, 2010a, p.6). The efficacy of competition laws also depend on ancillary legislations that establish the relevant enforcement agencies (hereafter, “competition agency”).

In addition, most AMSs have sectoral laws containing provisions that deal with competition-related matters. This is important when such sectors are excluded from a country's national competition law. These include Brunei (telecommunications), Malaysia (telecommunications and energy), the Philippines (Tariff Commission, Bureau of Trade Regulation and Consumer Protection, amongst others), Singapore (civil aviation, media services, energy and telecommunications) and Viet Nam (telecommunications, electricity, maritime, amongst others). ${ }^{9}$ 
Competition law can affect the implementation of competition and industrial policies either directly or indirectly. Competition law can provide a legal mandate for the competition agency to review government policies that may affect competition. Indonesia's competition law has such provisions. Competition law can also affect the implementation of competition and industrial policies indirectly by raising the awareness of the importance of competition as well as constrain stateowned and state-linked companies from undertaking activities that could lessen competition (provided such companies are not exempted from the law).

\section{Competition Law Implementation and Enforcement}

National competition law is a relatively new phenomenon in ASEAN. The first wave of implementation occurred in the aftermath of the 1997/1998 Asian Financial Crisis. Two AMSs that were severely affected by the crisis, Indonesia and Thailand, enacted their national competition laws in 1999. Since then, three more AMSs have joined the ranks of countries with national competition laws. The AEC has provided further impetus for the implementation of competition law in the region.

\subsection{Status of Implementation}

Amongst the ten AMSs, five have implemented comprehensive national (general) competition laws (Table 1). They are Indonesia, Malaysia, Singapore, Thailand and Viet Nam. Competition laws in these countries were implemented in three distinct waves. The decision to implement competition policy varied from one country to another. 
The first wave occurred immediately after the 1997/98 Asian Financial Crisis. Indonesia and Thailand implemented their national competition laws in 1999. Indonesia's decision to implement competition law was influenced by IMF assistance program (Pangestu, et al., 2002). Thailand's decision was purely internally driven and was facilitated by the passage of the country's new constitution in 1997 (Nikomborirak, 2006). In the second wave, trade-related factors influenced both Singapore and Viet Nam's decisions to implement competition laws in 2005. In Singapore's case, the Competition Act was enacted due to legal obligations set out in the U.S.-Singapore Free Trade Agreement (2003) (Ong, 2006). The WTO Accession was the main driver to Viet Nam's implementation of its competition law. The Malaysian government started drafting competition law as early as 1991 (Lee, 2005). Prior to the present law, two entirely different set of draft competition laws were completed (and subsequently abandoned). Malaysia finally implemented its competition law in 2010. The Malaysian government's decision to implement competition law was not influenced by the AEC Blueprint. 
Table 1: Competition Law Implementation in ASEAN

\begin{tabular}{|c|c|c|c|}
\hline & Implementation & Year & Details \\
\hline Brunei & No & - & $\begin{array}{l}\text { Sector provisions - Telecommunications Order } 2001 \\
\text { National competition law expected by } 2015\end{array}$ \\
\hline Cambodia & No & - & $\begin{array}{l}\text { Draft law under consideration - Council of Ministers } \\
\text { in } 2012\end{array}$ \\
\hline Indonesia & Yes & 1999 & $\begin{array}{l}\text { Law No.5 of } 1999 \\
\text { Agency: Komisi Pengawas Persaingan Usaha } \\
\text { (KPPU, Commission for Supervision of Business } \\
\text { Competition) }\end{array}$ \\
\hline Lao PDR & No & - & $\begin{array}{l}\text { Decree 15/PMO on Trade Competition to prohibit } \\
\text { restrictive business practices - enacted in } 2004 \text { but } \\
\text { not enforced } \\
\text { Agency - Trade Competition Commission (Ministry }\end{array}$ \\
\hline Malaysia & Yes & 2010 & $\begin{array}{l}\text { Competition Act } 2010 \\
\text { Agency: Malaysia Competition Commission (MyCC) }\end{array}$ \\
\hline Myanmar & No & - & $\begin{array}{l}\text { Article 36(b) of Constitution contains general } \\
\text { intention for competition policy } \\
\text { National competition law expected by } 2015\end{array}$ \\
\hline Philippines & No & - & $\begin{array}{l}\text { Competition-related provisions in the } 1987 \\
\text { Constitution, Revised Penal Code and New Civil } \\
\text { Code. Agency: Office for Competition (DOJ) } \\
\text { established in June 2011. Draft legislations under }\end{array}$ \\
\hline Singapore & Yes & 2005 & $\begin{array}{l}\text { Competition Act } \\
\text { Agency: Competition Commission of Singapore } \\
\text { (CCS) }\end{array}$ \\
\hline Thailand & Yes & 1999 & $\begin{array}{l}\text { Trade Competition Act B.E.2542 (1999) } \\
\text { Agency: Trade Competition Commission }\end{array}$ \\
\hline Viet Nam & Yes & 2005 & $\begin{array}{l}\text { Competition Law No.27/2004/QH11 } \\
\text { Agencies: Viet Nam Competition Authority } \\
\text { (investigation) and Viet Nam Competition Council } \\
\text { (adjudication) }\end{array}$ \\
\hline
\end{tabular}

Sources: ASEAN (2010b), DOJ website (Philippines)

Of the five remaining countries that have not implemented competition laws, three countries, namely, Cambodia, Lao PDR and the Philippines have draft competition laws under discussions either at the ministerial level (Cambodia and Lao 
PDR) or legislatures (the Philippines). In the case of the Philippines, the Executive Order No.45 dated 9 June 2011 designated the Office for Competition, Department of Justice (OFC) as the competition authority. Pending the enactment of a national competition law, the OFC will draw from existing legislations that have competitionrelated provisions. In this regard, the agency will work in partnership with different government agencies which implement/enforce competition law, or regulate/monitor anti-competitive behavior, at the sectoral level on the basis of competition-related laws within their purview. Despite these recent developments, the Philippines is not counted as having a comprehensive national competition law - as two different draft legislations are currently be considered in the country's parliament. Two countries, Brunei and Myanmar have yet to draft their competition laws.

\subsection{Comparative Analysis of Competition Laws}

There are significant differences in competition laws of the five AMSs which have such laws. A number of factors may have contributed to this such as negotiations/discussions between stakeholders during the drafting stages, prevailing best-practices, and influences from different existing competition laws (transplant or model laws).

Competition laws in AMSs differ in terms of a number of dimensions. These include the objectives of the law, content/provisions, legal standard (per se vs. ruleof-reason) and the form as well as quantum of sanctions. This is an important topic in the context of the AEC. The implications of these differences such as their impacts on transactions costs and cross-border investments are explored in greater detail in the next section. In the rest of this section, we examine some of these key differences. 


\section{(a) Objectives}

The objectives of competition laws are important for they provide the reasons for having such laws in the first place and also because they influence the manner in which such laws are drafted, implemented and enforced. Even though the objectives of competition law are important, they are often not explicitly stated in the law in itself. In such cases, they can be inferred from statements and speeches from enforcement agencies or ministries. It is perhaps important to state such objectives if a particular competition law is expected to achieve goals (e.g. development) other than those which are normally associated with competition laws (e.g. efficiency and consumer welfare).

Table 2 provides a summary of some of objectives associated with competition laws in AMSs. Almost all competition laws in these countries list efficiency and consumer welfare as the objectives of their competition law. Both Indonesia and Thailand place importance on free and fair trade. Competitiveness is an important objective for Indonesia and Singapore but they differ in terms of emphasis - firmlevel (Indonesia) vs. economy-level (Singapore). Finally, both Malaysia and Thailand emphasize development as one of the competition law's objective.

The presence of multiple objectives may run the risk of conflicting objectives. For example, the development and competitiveness objectives may conflict with efficiency and consumer welfare objectives. As expected, none of the laws has regional integration as an objective, given that the AEC was only declared in 2003 with 2020 as its deadline (subsequently brought forward to 2015). This point is worth emphasizing because in jurisdictions where regional integration is an important objective, such as the European Union, competition law may focus on both competition as well as single market integration. 
Despite recent arguments that competition law can serve both competition and regional integration, there can be a conflict between the two objectives (Jones \& Suffrin, 2011, p.43). For example, the inter-penetration of new markets may require marketing expenses that can only be recovered via retail price maintenance or territorial restrictions which are considered anti-competitive practices (ibid, pp.695696). In the cases of AMSs, national development and competitiveness objectives may also conflict with a regional integration objective. For example, a country's intent on making its industry "competitive" internationally via ensuring larger domestic production (e.g. to achieve scale economies) may restrict imports - a move that is against regional integration. Sectoral interdependence may also result in a reduction in the overall national competitiveness due to protection of selected industries which raises input costs of other industries.

Table 2: Objectives of Competition Law

\begin{tabular}{lcccc}
\hline & $\begin{array}{c}\text { Efficiency } \\
\text { Welfare }\end{array}$ & $\begin{array}{c}\text { Consumer } \\
\text { Development }\end{array}$ & $\begin{array}{c}\text { Economic } \\
\text { Competitiveness }\end{array}$ & $\begin{array}{c}\text { Free and Fair } \\
\text { Trade }\end{array}$ \\
\hline \hline Indonesia & $\checkmark$ & $\checkmark$ & $\checkmark$ (firms) & $\checkmark$ \\
Malaysia & $\checkmark$ & $\checkmark$ & $\checkmark$ (economy) & $\checkmark$ \\
Singapore & $\checkmark$ & $\checkmark$ & \\
Thailand & $\checkmark$ & & \\
Viet Nam & $\checkmark$ & $\checkmark$ & \\
\hline $\begin{array}{l}\text { Sources: Authors - based on Competition Act 2010 (Malaysia), Department of Trade \& Industry } \\
\text { website (Singapore), Tran (2007), KPPU website. }\end{array}$
\end{tabular}

\section{(b) Contents / Provisions}

The competition laws in AMSs may have similar objectives but there remain significant differences especially in terms of threshold levels and sanctions. ${ }^{10}$ This is evident from a comparison of the competition laws of the five AMSs. 
In the area of horizontal anti-competitive agreements, these competition laws differ in terms of the presence and size of market threshold levels (Table 3). No threshold levels are specified for the assessment of horizontal anti-competitive agreements in the competition laws of Thailand and Malaysia. For countries with threshold specification(s), it differs from one country to another.

Table 3: Horizontal Anti-Competitive Agreements

\begin{tabular}{|c|c|c|c|c|}
\hline & Item & $\begin{array}{c}\text { Market Share } \\
\text { Threshold }\end{array}$ & Legal Standard Applied & Sanctions \\
\hline $\begin{array}{l}\text { Indonesia } \\
\end{array}$ & Art. 5-12 & "Group-75\% & $\begin{array}{l}\text { Per se illegal for price fixing, } \\
\text { area distribution, boycotting, } \\
\text { cartel trust }\end{array}$ & $\begin{array}{l}\text { Administrative: } \\
\text { Min. Rp.1 bil, Max. Rp. } 25 \text { bil } \\
\text { Criminal: } \\
\text { Min. Rp. } 1 \text { bil, Max. Rp. } 25 \text { bil or Max } 5 \\
\text { months imprisonment }\end{array}$ \\
\hline Malaysia & $\begin{array}{ll}\text { Sec. } 4 \\
\end{array}$ & - & $\begin{array}{l}\text { Per se illegal for price fixing, } \\
\text { share market and source supply, } \\
\text { limit/control production, } \\
\text { distribution, } \\
\text { technical/technological } \\
\text { development, investment and } \\
\text { bid-rigging }\end{array}$ & $\begin{array}{l}\text { For offenses involving corporate body: } \\
\text { First time -Max. RM } 5 \text { million } \\
\text { Repeated Offense } \\
\text { Max. RM10 million } \\
\text { For offenses involving non-corporate } \\
\text { body: } \\
\text { Max. RM1 million or/and } \\
\text { Max. } 5 \text { years imprisonment } \\
\text { Repeat offense: } \\
\text { Max. } 2 \text { million and/or } 5 \text { years } \\
\text { imprisonment } \\
\text { For infringements, the financial penalty is } \\
\text { a maximum of } 10 \% \text { of worldwide turnover } \\
\text { for the period during which the } \\
\text { infringement occurred }\end{array}$ \\
\hline Singapore & Sec. 34 & $\begin{array}{l}\text { Group -20\% } \\
\text { Individual-25\% } \\
\text { SMEs }\end{array}$ & $\begin{array}{l}\text { Per se illegal for price-fixing, } \\
\text { bid-rigging, market-sharing or } \\
\text { output limitations } \\
\text { Rule of reason (Net Economic } \\
\text { Benefit Test) for others }\end{array}$ & $\begin{array}{l}\text { Financial penalty: } \\
\text { Max. } 10 \% \text { of the turnover for each year of } \\
\text { infringement for maximum period of } 3 \\
\text { years }\end{array}$ \\
\hline Thailand & Sec. 27 & $\begin{array}{l}\text { A business operator : } 50 \% \\
\text { Market share and } 1 \\
\text { trillion Baht } \\
\text { Top three business } \\
\text { operator : } 75 \% \text { Market } \\
\text { share and } 1 \text { trillion Baht } \\
\text { Exception : a business } \\
\text { operator with market } \\
\text { share less than } 10 \% \text { or } \\
\text { turnover less than } 1 \\
\text { trillion Baht }\end{array}$ & $\begin{array}{l}\text { Per-se illegal for price-fixing, } \\
\text { restrictions on production, } \\
\text { purchase and sale }\end{array}$ & $\begin{array}{l}\text { Max. Baht } 6 \text { million or/and } \\
\text { Max. } 3 \text { years imprisonment } \\
\text { Repeat offense - double penalty }\end{array}$ \\
\hline Viet Nam & Art. 8 & Group-30\% & $\begin{array}{l}\text { Per-se illegal for price-fixing, } \\
\text { distribution outlets, restrictions } \\
\text { on production, purchase and } \\
\text { sale, restrictions on technical } \\
\text { and technological development, } \\
\text { restrictions on investments, tied } \\
\text { sale/contracts, market } \\
\text { exclusion, bid-rigging }\end{array}$ & Max. $10 \%$ of turnover \\
\hline
\end{tabular}

Source: Compiled by authors 
The legal standards applied may also differ across AMSs. Indonesia, Malaysia, Thailand and Viet Nam consider horizontal anti-competitive agreements to be per se illegal while Singapore regards certain types of such agreements to be per se illegal. The applicable sanctions for such agreements also vary significantly across ASEAN countries in terms of various dimensions such as criminal vs. civil (financial) penalty, basis (\% of turnover or lumpsum) and quantum (fine amount or length of prison sentence).

Similar types of variations can be found in the case of provisions related to abuse of dominance (Table 4) and merger controls (Table 5). In the case of merger controls, Malaysia stands out as not having any provisions on merger controls. Merger controls in Thailand is currently non-operational due to the absence of any threshold specifications.

The above differences are worth emphasizing given the goal of single market and production base in the AEC. Within the EU, for example, mergers involving concentrations with community dimension requires are view by the European Commission. ${ }^{11}$ In so far as mergers do not have such dimensions, they are evaluated on the basis of national merger controls. Such mergers controls can be harmonized without the creation of a single enforcement body at the regional level. 
Table 4: Abuse of Dominance

\begin{tabular}{|c|c|c|c|c|}
\hline & Item & $\begin{array}{c}\text { Dominant } \\
\text { Position } \\
\text { Threshold }\end{array}$ & Conduct & Sanctions \\
\hline Indonesia & Art. 25 & $\begin{array}{l}\text { Individual-50\% } \\
\text { Group-75\% }\end{array}$ & $\begin{array}{l}\text { Impose trade terms that hamper } \\
\text { consumers from acquiring } \\
\text { competitive goods and/or } \\
\text { services, restrict the market } \\
\text { and technology development, } \\
\text { hamper firms potential } \\
\text { competitors from entering } \\
\text { market. }\end{array}$ & $\begin{array}{l}\text { Administrative: } \\
\text { Min. Rp.1 bil, Max. Rp. } 25 \text { bil } \\
\text { Criminal: } \\
\text { Min. Rp.1 bil, Max. Rp. } 25 \text { bil } \\
\text { or } \\
\text { Max } 5 \text { months imprisonment }\end{array}$ \\
\hline Malaysia & Sec.4 & $\begin{array}{l}\text { No threshold - to } \\
\text { maintain flexibility }\end{array}$ & $\begin{array}{l}\text { Impose unfair trading terms on } \\
\text { supplier/customer, limit/control } \\
\text { production, market outlets or } \\
\text { market access, technological } \\
\text { development/ investment, } \\
\text { refusing to supply, discriminate } \\
\text { to discourage entry or } \\
\text { expansion, predatory behavior, } \\
\text { tie contract to unrelated } \\
\text { supplementary conditions, } \\
\text { vertical exclusion of } \\
\text { competitors. }\end{array}$ & $\begin{array}{l}\text { For offenses involving } \\
\text { corporate body: } \\
\text { First time-Max. RM } 5 \text { million } \\
\text { Repeated Offense } \\
\text { Max. RM10 million } \\
\text { For offenses involving non- } \\
\text { corporate body: } \\
\text { Max. RM1 million or/and } \\
\text { Max. } 5 \text { years imprisonment } \\
\text { Repeat offense: } \\
\text { Max. } 2 \text { million and/or } \\
5 \text { years imprisonment } \\
\text { For infringements, the financial } \\
\text { penalty is a maximum of } 10 \% \\
\text { of worldwide turnover for the } \\
\text { period during which the } \\
\text { infringement occurred }\end{array}$ \\
\hline Singapore & $\begin{array}{l}\text { Sec. } \\
47\end{array}$ & $\begin{array}{l}\text { No official } \\
\text { threshold but } 60 \% \\
\text { is used as a guide } \\
\text { Unlikely for SMEs }\end{array}$ & $\begin{array}{l}\text { Predatory behavior, restrictions } \\
\text { on production, markets, or } \\
\text { technical development, } \\
\text { discrimination that put trading } \\
\text { parties at a competitive } \\
\text { disadvantage. Tie contracts } \\
\text { with unrelated supplementary } \\
\text { obligations }\end{array}$ & $\begin{array}{l}\text { Financial penalty: } \\
\text { Max. } 10 \% \text { of the turnover for } \\
\text { each year of infringement for } \\
\text { maximum period of } 3 \text { years }\end{array}$ \\
\hline Thailand & $\begin{array}{l}\text { Sec. } \\
25\end{array}$ & $\begin{array}{l}50 \% \text { or THB1 } \\
\text { trillion }\end{array}$ & $\begin{array}{l}\text { Price fixing, fixing compulsory } \\
\text { trading conditions, disruption } \\
\text { and restriction of services, } \\
\text { production, purchase, } \\
\text { distribution, intervening in the } \\
\text { operation of business without } \\
\text { justifiable reasons. }\end{array}$ & $\begin{array}{l}\text { Max. Baht } 6 \text { million or/and } \\
\text { Max. } 3 \text { years imprisonment }\end{array}$ \\
\hline Viet Nam & Art. 11 & $\begin{array}{l}\text { One firm }-30 \% \\
\text { Two firms - 50\% } \\
\text { Three firms - 65\% } \\
\text { Four firms - 75\% }\end{array}$ & $\begin{array}{l}\text { Predatory pricing, pricing that } \\
\text { causes damage to customers, } \\
\text { restricting production and } \\
\text { distribution that causes damage } \\
\text { to customers, discrimination } \\
\text { to create inequality in } \\
\text { competition, tie unrelated } \\
\text { obligations to sale, preventing } \\
\text { market entry. }\end{array}$ & Max. $10 \%$ of turnover \\
\hline
\end{tabular}

Source: Compiled by authors. 
Table 5: Merger Controls

\begin{tabular}{|c|c|c|c|c|}
\hline & Item & Type & Threshold & Sanctions/Remedies \\
\hline Indonesia & $\begin{array}{l}\text { Art. 28- } \\
29\end{array}$ & $\begin{array}{l}\text { Pre-merger } \\
\text { Notification } \\
\text { Voluntary } \\
\text { Within } 30 \\
\text { days of } \\
\text { merger }\end{array}$ & $\begin{array}{l}\text { Consolidated assets > } \\
\text { Rp.2.5 trillion } \\
\text { Consolidated turnover } \\
\text { > Rp.5 trillion } \\
\text { Banks: } \\
\text { Consolidated assets > } \\
\text { Rp.20 trillion }\end{array}$ & $\begin{array}{l}\text { Administrative: } \\
\text { Revoke merger } \\
\text { Criminal: } \\
\text { Min. Rp.25 bil, Max. } \\
\text { Rp.100 bil or } \\
\text { Max. } 6 \text { months } \\
\text { imprisonment }\end{array}$ \\
\hline Malaysia & Sec. 4 & NA & NA & NA \\
\hline Singapore & Sec. 34 & $\begin{array}{l}\text { Voluntary } \\
\text { self- } \\
\text { assessment - } \\
\text { for pre \& } \\
\text { post-merger }\end{array}$ & $\begin{array}{l}\text { Market share of } 40 \% \text { or } \\
\text { more or } \\
\text { Market share of } 20 \%- \\
40 \% \text { and post-merger } \\
\text { CR3 at } 70 \% \text { or more }\end{array}$ & $\begin{array}{l}\text { Structural: } \\
\text { Sale or divestiture } \\
\text { Behavioural: } \\
\text { Commitment to specified } \\
\text { conduct }\end{array}$ \\
\hline Thailand & Sec. 26 & Compulsory & Not issued & $\begin{array}{l}\text { No sanctions due to } \\
\text { absence of notification } \\
\text { thresholds }\end{array}$ \\
\hline Viet Nam & Art. 8 & Compulsory & $\begin{array}{l}\text { Market share of } 30 \%- \\
50 \%\end{array}$ & $\begin{array}{l}\text { Financial penalty: } \\
1-3 \% \text { of turnover }\end{array}$ \\
\hline
\end{tabular}

Note: NA - not applicable

Source: Compiled by authors

\subsection{Enforcement Performance}

The earliest AMSs to implement competition law such as Indonesia and Thailand have had at least ten years of enforcement experience. An assessment of the performance of competition law regimes in these countries as well as newer ones is an important exercise. Many factors may impinge on the performance of a given competition regime - some exogenous while others were determined by the ways in which the law itself was drafted as well as the manner in which the enforcement agency was set up. An assessment of enforcement performance of existing competition law regimes provides an opportunity for newer competition regimes (as well as countries intending to establish one) to learn valuable lessons. This subsection provides a brief assessment of the performance of competition law regimes in 
AMSs with such laws. There is currently no comprehensive and consistent database on competition law enforcement in AMSs. What follows is based on data collected from the websites of the enforcement agencies and other secondary sources. The review is confined to only five countries that have implemented comprehensive national competition laws, namely, Indonesia, Malaysia, Singapore, Thailand, and Viet Nam.

\section{(a) Indonesia}

Amongst AMSs with competition law, Indonesia can claim to have the most mature competition regime in terms of enforcement experience. KPPU, the enforcement agency, has handled a total of 249 cases during the period 2000-2010. Despite some fluctuations in the number of cases handled in recent years, there is an overall upward trend in the cases handled since KPPU's establishment (Table 6). This has been made possible by the cumulative knowledge and growth in manpower. KPPU's total employees have increased ten-fold in the past decade from 31 in 2000 to 353 in 2010 (KPPU, Annual Report 2010, p.40).

Close to $87 \%$ of the cases handled thus far has originated from reports filed by the public (compared to those initiated by KPPU). An interesting feature of KPPU's experience is the disproportionately large share of cases dealing with collusive bidding. Collusive bidding account for more than $80 \%$ of the cases handled by KPPU since 2000 (KPPU Annual Report 2009, p.30). Another unique feature of Indonesia's experience is the legally-mandated role that it plays in providing recommendations and considerations to the Indonesian government on the consistency of its policies with principles of fair competition. Such submissions have averaged about ten per annum in recent years. Some of these submissions have been influential. For example, based on KPPU's recommendation, the Indonesian 
Ministry of Transport prohibited the setting of domestic airline tariff via the Indonesian National Air Carriers Association in 2002 (Aswicayahyono \& Kartika, 2010).

An area in competition law enforcement which has lagged in recent years is merger controls. Even though the law mandates merger notification, guidelines and regulations pertaining to merger notification were only announced in 2010. In that year, seven cases were handled.

Table 6: Competition Enforcement in Indonesia, 2000-2010

\begin{tabular}{|c|c|c|c|c|c|c|c|c|c|c|c|}
\hline & 2000 & 2001 & 2002 & 2003 & 2004 & 2005 & 2006 & 2007 & 2008 & 2009 & 2010 \\
\hline No. of cases handled & 2 & 5 & 8 & 9 & 9 & 22 & 18 & 31 & 68 & 35 & 42 \\
\hline $\begin{array}{l}\text { Cases reported by } \\
\text { public }\end{array}$ & 1 & 4 & 5 & 5 & 7 & 18 & 15 & 28 & 66 & 30 & 38 \\
\hline $\begin{array}{l}\text { Cases initiated by } \\
\text { KPPU }\end{array}$ & 1 & 1 & 3 & 4 & 2 & 4 & 3 & 3 & 2 & 5 & 4 \\
\hline $\begin{array}{l}\text { Cases with no } \\
\text { infringement }\end{array}$ & 1 & 4 & 6 & 3 & 2 & 7 & 12 & 6 & 26 & 5 & 12 \\
\hline $\begin{array}{l}\text { Cases with } \\
\text { infringement }\end{array}$ & 1 & 1 & 2 & 6 & 7 & 15 & 6 & 25 & 42 & 30 & 30 \\
\hline $\begin{array}{l}\text { Number of } \\
\text { Employees }\end{array}$ & & 31 & 44 & 70 & 81 & 88 & 104 & 163 & 206 & 252 & 353 \\
\hline Budget (Rp., billion) & 5.99 & 20.75 & 15.64 & 24.92 & 22.99 & 42.3 & 84.5 & 85.0 & 86.94 & 82.09 & 82.31 \\
\hline
\end{tabular}

Source: KPPU Annual Report 2010

\section{(b) Malaysia}

Malaysia has also adopted a gradual approach to the enforcement of competition law. Gazetted in June in 2010, the Competition Act 2010 only came into force on January 1, 2012. Prior to this, the Malaysia Competition Commission (MyCC) focused its activities on advocacy activities and drafting of enforcement guidelines (complaint procedures, market definition and anti-competitive agreement). In late 2012, the MyCC issued its first infringement decision on the Cameron Highlands Floriculturist 
Association (CHFA) based on the latter's attempt at price fixing in the local retail and wholesale flower markets. In the case, no financial penalties were imposed as CHFA had agreed to cease its price fixing activity.

\section{(c) Singapore}

The Competition Commission of Singapore (CCS) was established in 2005. Enforcement followed a sequential approach in which provisions on anti-competitive agreement and abuse of dominance came into force in 2006 followed by merger controls in 2007. Since its establishment, CCS has successfully investigated cases covering a wide range of anti-competitive business practices such as bidding rigging (pest control, 2008; electrical and building works), price-fixing (coach operators, 2008; employment agencies, 2011; modeling agencies, 2011) and abuse of dominance (ticketing, 2009). By bringing these cases to a successful conclusion, CCS has been able to significantly enhance their credibility and reputation. Since its merger controls came into effect in 2007, CCS has also been actively looking into merger notification cases (Table 7). This is not surprising given Singapore's role as a major international commercial and financial hub in the region.

Table 7: Competition Enforcement in Singapore, 2006-2011

\begin{tabular}{lcccccc}
\hline & $\mathbf{2 0 0 6}$ & $\mathbf{2 0 0 7}$ & $\mathbf{2 0 0 8}$ & $\mathbf{2 0 0 9}$ & $\mathbf{2 0 1 0}$ & $\mathbf{2 0 1 1}$ \\
\hline \hline & & & & & & \\
No. of cases handled & 10 & 14 & 35 & 25 & 36 & 26 \\
Preliminary investigations & & & 18 & 16 & 15 & 8 \\
Notification for guidance & 7 & 3 & 2 & 0 & 1 & 4 \\
Notifications for decision & 3 & 3 & & 0 & 1 & 3 \\
Merger notification & & 6 & 8 & 3 & 6 & 8 \\
Appeals & & & & 0 & 3 & 0 \\
Competition advisories & & & 6 & 6 & 5 & 4 \\
Market studies & & & & 0 & 5 & 2 \\
Leniency application & 5.9 & 7.3 & 9.8 & 10.5 & 13.0 & \\
Expenditure (SD, million) & & & & & & \\
\hline
\end{tabular}

Source: CCS Annual Reports 
Under Section 36 of the Competition Act, the Minister for Trade and Industry may make an order (i.e. Block Exemption Order), at CCS' recommendation, to exempt a particular category of agreements from the Section 34 prohibition on anticompetitive agreements, decisions and practices. In this regard, a Block Exemption Order for Liner Shipping Agreements is in force until 31 December 2015.

CCS is currently in the process of reviewing its procedural guidelines for mergers. The key aims of the review are to increase the transparency of CCS' merger review procedures, to streamline the process of merger notification in order to minimise the burdens on businesses and to maximise the benefits of Singapore's voluntary merger notification system.

CCS also has an effective leniency program in place to encourage businesses that have participated in cartel activities, to come forward with information and evidence about the cartel. Businesses that do not have substantial information or evidence of the cartel may still apply for a leniency marker and thereafter collect the information or evidence required to support their leniency application.

In April 2010, CCS amended the Competition (Financial Penalties) Order to provide for the payment of financial penalties in instalments; and the charging of interest on the said instalment payments and late payment of financial penalties.

\section{(d) Thailand}

Thailand (together with Indonesia in 1999) was one of the first ASEAN countries to implement competition law. However, unlike Indonesia, much of the momentum in enforcement was lost in the early years of the law due to a number of factors. Between 1999 and 2011, some 79 complaints were lodged (Table 8). Thus far, only seven cases have been identified as involving anti-competitive business 
practices $^{12}$ Of these, two (international franchise and day old chicks trade) were settled, one was terminated when the company involved exited the business and four other cases were further investigated. The fate of these four cases illustrates the type of problems experienced in enforcing competition law in Thailand:

- Abuse of dominance in cable TV market (2001) - terminated due to lack of threshold for dominance

- Tying of sale of whisky and beer (2002) - terminated due to lack of threshold for dominance

- Predatory pricing by multinational supermarkets (2001) - terminated due to lack of threshold for dominance and also reclassified as more relevant to Wholesale Trade Act

- Abuse of dominance (exclusive dealing) in motorcycle industry (2001-2003) - terminated due to errors in procedures and reclassified as unfair trade practices

Clearly, significant amount of resources were expended in these highly publicized cases in the early years of the law's enforcement. In the end, lack of clear rules and procedures as well as a host of other factors (such as lack of independence and transparency) resulted in failure to bring these cases to a successful conclusion, thus undermining the morale and reputation of the Trade Competition Commission (TCC). Furthermore, both the TCC and the Office of Competition Commission (OCC) lacked resources to function effectively. For example, the staff size and budget of the OCC is estimated to be around 30 employees and USD100,000. This is small compared to the size of KPPU's resources of around 300+ staff and USD10 million+ budget. 
Table 8: Competition Enforcement in Thailand, 2000-2011

\begin{tabular}{|c|c|c|c|c|c|c|c|c|c|c|c|c|c|}
\hline & 1999 & 2000 & 2001 & 2002 & 2003 & 2004 & 2005 & 2006 & 2007 & 2008 & 2009 & 2010 & 2011 \\
\hline $\begin{array}{l}\text { No. of } \\
\text { complaints }\end{array}$ & 2 & 4 & 7 & 77 & 13 & 12 & 9 & 7 & 9 & 4 & 1 & 1 & 3 \\
\hline $\begin{array}{l}\text { Abuse of } \\
\text { dominant } \\
\text { position }\end{array}$ & 1 & 2 & 3 & 2 & 3 & 0 & 0 & 0 & 3 & 0 & 1 & 0 & 0 \\
\hline $\begin{array}{l}\text { Mergers and } \\
\text { Acquisition }\end{array}$ & 0 & 0 & 0 & 0 & 0 & 0 & 0 & 0 & 0 & 0 & 0 & 0 & 0 \\
\hline $\begin{array}{l}\text { Restrictive } \\
\text { Agreements }\end{array}$ & 0 & 0 & 1 & 1 & 8 & 3 & 2 & 1 & 1 & 0 & 0 & 0 & 0 \\
\hline $\begin{array}{l}\text { Unfair trade } \\
\text { practices }\end{array}$ & 1 & 2 & 3 & 4 & 2 & 9 & 7 & 6 & 5 & 4 & - & 1 & 3 \\
\hline
\end{tabular}

Source: Trade Competition Commission

\section{(e) Viet Nam}

Viet Nam has adopted a gradualist approach to the enforcement of its competition law. Like its counterpart (Singapore) which implemented competition law in the same year (2005), the Vietnam Competition Authority (VCA) has chosen the path of selecting a few cases to build its expertise and reputation.

Between 2007 and 2010, VCA investigated four cases of anti-competitive business practice. Of these, two involved abuse of dominance position, one abuse of monopoly position and another anti-competitive agreement. Their statuses are as follow:

- Abuse of dominance case in aviation fuel supply (2008-2009) - finding of infringement, submitted to Vietnam Competition Council (VCC) for decision-making

- Abuse of dominance in beer market (2007-2010) - terminated due to lack of evidence

- Price fixing in non-life insurance market (2008-2010)- finding of infringement

- Abuse of dominance in distribution of imported movies - on-going investigation 
VCA is clearly having some early success in bringing some of cases investigated to a close. In addition, it is also currently active in merger evaluations. It has received 8 merger notifications and 30 requests for consultation (VCA, Annual Report 2010). The above examples clearly suggest that VCA is moving in the right direction in terms of building up enforcement capacity and reputation.

Overall, the performance in both the implementation and enforcement of competition law amongst AMSs is clearly a mixed one. This is evident from a review of the implementation status as well as the enforcement performance in AMSs. The key challenges in the introduction of competition law are: (i) the government's understanding of the benefits of competition law, and (ii) the lack of public awareness. In this regard, the careful selection of competition cases with high public interest and reasonable chance of success can be a crucial strategy for both capacity building as well as to convince the government and the public of the importance of competition law. The experiences of Indonesia, Singapore and Viet Nam support this view. For countries about to embark on implementing competition law, these insights ought to be combined with the importance of getting the institutional procedures right (as the Thai case illustrates).

\section{Competition Policy and Regional Cooperation in the AEC Blueprint}

Competition plays an important role in the realization of the AEC. This recognition has led to the incorporation of competition policy as a key element in the AEC Blueprint. Specific targets and milestones for the implementation of 
competition policy have been incorporated in the AEC Blueprint. ASEAN regional cooperation on competition policy in recent years has been driven by these targets and milestones.

"Competition policy" is one of the six items under the goal of "competitive economic region” in the AEC Blueprint. The other five items are consumer protection, intellectual property rights, infrastructure development, taxation and ecommerce. This placement within the section on "competitive economic region" implies that the effective implementation of competition policy can enhance the competitiveness of ASEAN as an economic community or region. This is appropriate given the importance of competition in ensuring the efficient allocation of resources.

In the AEC Blueprint, five actions or targets for competition policy were listed. Each of these is reviewed below. In assessing the degree of achievement or implementation, we assign three labels, namely, "high” (action fully implemented by all AMSs or designated body), “moderate” (action not fully implemented but by more than half of AMSs), and "low” (implementation by less than half of AMSs).

\section{(a) Implementation of Competition Law}

The first action on competition policy relates to the implementation of competition law in AMSs. It reads: "Endeavour to Introduce Competition Policy in all ASEAN Member Countries by 2015.” The level of implementation could be measured using either a broad or narrow interpretation of "competition policy". In both cases, the level of implementation is moderate - based on the number of countries (five out of ten) that have enacted national competition laws. If a broad interpretation is used, namely, competition policy as "a governmental policy that 
promotes or maintains the level of competition in markets”, it can be concluded that most but not all AMSs have implemented such policies. ${ }^{13}$ Further progresses are needed in the areas of non-tariff barriers, market liberalization and privatization.

In terms of competition law, five AMSs (Indonesia, Malaysia, Singapore, Thailand and Viet Nam) have implemented comprehensive national competition laws. Three countries (Cambodia, Lao PDR and the Philippines) are either in the process of drafting or have drafts under review. Brunei and Myanmar have intention to begin the process of drafting competition law. It is perhaps useful to note that even though these countries have not implemented comprehensive national competition laws, a number of these countries have laws that deal with some aspects of competition. These include the Philippines (see Section 4) and Brunei (in telecommunications sector). In the case of the Philippines, despite having two draft versions being deliberated at the House and Senate, the country has gone ahead with establishing the OFC under the Department of Justice as the enforcement agency for competition policy (Aldaba, 2012). Under the Executive Order No.45, the agency has a very wide mandate that goes beyond competition-related matters, e.g. unfair trade practices, corruption, regulatory governance and trade.

Overall, there is a need for further emphasis on assisting implementation of competition law for Brunei, Cambodia, Lao PDR and Myanmar. These countries are small (with the exception of Myanmar) and/or have very low per capita income levels (with the exception of Brunei) - thus face considerable challenges in terms of lack of expertise and financial resources (see Section 2).

In addition, the implementation of competition law in some of these countries needs to take into account their small size. The achievement of scale economies is difficult in small market economies and such markets tend to be dominated by a few 
large firms. As such, these countries may consider merger controls that are more accommodating of efficiency defenses and less emphasis on per se rule prohibitions on cooperative agreements involving SMEs (Gal, 2001 \& Gal, 2003). This also implies that the cost-benefit analysis of implementing competition law in such countries is likely to depend on how competition law is implemented and when they are implemented.

The experiences from AMSs that have implemented competition law may imply that the moderate achievements in countries that have not enacted competition law may not necessarily be a bad thing. Successful enforcement of competition law requires both strong domestic public as well as political support and adequate manpower and financial resources. Without these pre-conditions, the drafting process and enactment of competition law may result in a dysfunctional competition regime.

\section{(b) Establishment of Competition Policy Network}

The second action on competition policy relates to the establishment of a competition policy network involving AMSs. The action is stated in the Blueprint as: "Establish a network of authorities or agencies responsible for competition policy to serve as a forum for discussing and coordinating competition policies.”

The level of implementation for the above action can be considered to be high based on the establishment and activities of the ASEAN Experts Group on Competition (AEGC). The network of authorities or agencies is anchored around AEGC which was established in 2007. The AEGC is a formal body comprising representatives from all AMSs nominated by SEOM Leaders from respective country. The AEGC was established with the mandate of overseeing competition 
related matters in ASEAN. This includes the achievement of competition-related goals in the AEC Blueprint. As of June 2012, the AEGC has had nine meetings since its establishment. The significant contributions of the AEGC can be seen from its activities which are carried out via its five working groups, namely:
a) regional guidelines on competition policy
b) handbook on competition policy and law in ASEAN for business
c) capacity building
d) regional core-competencies in competition policy and law, and
e) strategy and tools for regional competition advocacy.

Three of these working groups, namely (a), (b) and (c), focus specifically on undertaking activities directly related to the AEC Blueprint, principally, action (3) on capacity building and the Blueprint action (4) on the development of regional guidelines on competition policy. Both the working groups on regional guidelines and handbook have completed the respective documents with the latter scheduled to be updated in 2013.

The activities of the working group on capacity building continue to be very important for AMSs (Table 9). Between 2008 and 2011, it has organized 14 capacity building activities involving 700 government officials from AMSs.

Table 9: AEGC Activities, 2008-2012

\begin{tabular}{lccccc}
\hline & $\mathbf{2 0 0 8}$ & $\mathbf{2 0 0 9}$ & $\mathbf{2 0 1 0}$ & $\mathbf{2 0 1 1}$ & $\mathbf{2 0 1 2}$ \\
\hline \hline Capacity Building & 2 & 6 & 3 & 3 & 5 \\
Policy Dialogue/Conferences/Outreach & 1 & 4 & 4 & 1 & \\
Brainstorming Sessions & & & 2 & & \\
ASEAN Guidelines on CP & & 2 & 1 & & 2 \\
Handbook on CP & & 1 & 1 & & \\
Regional core competencies & 2 & 3 & & & \\
Others - Foundation laying, stock -taking, & 2 & & & & \\
study visit & 5 & $\mathbf{1 6}$ & $\mathbf{1 1}$ & $\mathbf{6}$ & $\mathbf{7}$ \\
\hline Total & & & & &
\end{tabular}


As the AEGC matures and as more AMSs implement competition law, more attention is being paid on the issue of regional core competencies. This is reflected in the three workshops on developing regional core competencies held in the past two years in Singapore, Indonesia and Thailand. The working group on regional core competencies is currently developing a manual of regional core competencies in three major focus areas, namely: (i) institutional building, (ii) enforcement and (iii) advocacy. The final draft of manual is expected to be completed by the end of 2012 .

Finally, the working group on advocacy will begin developing tools for customized advocacy strategies in 2012. In addition, efforts are also under way to collect and compile case studies from the AMSs. This activity will be useful in documenting and assessing the benefits from implementing competition policy in the region.

Overall, the high frequency and range of activities organized by AEGC and involving officials from AMSs suggest that the competition policy network anchored around the AEGC is fairly strong (Table 9). In addition, AEGC has recently embarked on initiatives aimed establishing higher-levels of cooperation involving competition agencies and competition-related agencies from AMSs.

\section{(c) Capacity Building Programs and Activities}

The third action listed in the AEC Blueprint focuses on capacity building activities aimed at developing national competition policy in AMSs. The action was formally stated in the Blueprint in the following manner: "Encourage capacity building programmes/activities for ASEAN Member Countries in developing national competition policy.” 
The level of implementation for the third action is fairly high based on the number of capacity building-related activities that have been carried out since 2008 . In this regard, the AEGC has played an instrumental role in organizing capacity building activities such as workshops and conferences in the region. It has organized 19 capacity workshops between 2008 and 2012. Given that competition policy and law is a relatively new phenomenon in the ASEAN region, the capacity building activities have focused on a number of key areas, namely (Table 10):

- Advocacy,

- Objectives and benefits of competition policy,

- Scope of competition policy, and

- International cooperation.

As more AMSs implement competition law, the focus of such activities is likely to shift more towards international-cooperation and enforcement-related activities in the future. In addition, as AMSs gain further experiences in enforcement, intraASEAN sharing of experiences is likely to become more frequent.

The host countries for these capacity-building activities can benefit significantly via its ability to send more country participants. In this respect, the sequencing of capacity building activities across AMSs suggests that there has been more emphasis on countries that have either recently implemented comprehensive competition law (such as Viet Nam and Malaysia) or have not done so (Brunei, Cambodia and Lao PDR) (Table 11). In this regard, a potentially important issue is the resources available at small AMSs with low per capita income that have yet to implement competition law. Whilst financial resources can be obtained via funding from external agencies, the lack of human resources may be a more difficult problem to tackle. Thus, whilst capacity building activities are more urgent in such countries, 
resource constraints in these countries are more severe. Finally, plans are already afoot to develop such a pool of experts under the ASEAN-GIZ Project on Competition Policy and Law (CPL). When implemented, this initiative is likely to enhance the capacity building process in the area of competition law in AMSs.

Table 10: Areas of Focus in AEGC's Capacity Building Activities, 2008-2012

\begin{tabular}{lccccc}
\hline Area of Focus & $\mathbf{2 0 0 8}$ & $\mathbf{2 0 0 9}$ & $\mathbf{2 0 1 0}$ & $\mathbf{2 0 1 1}$ & $\mathbf{2 0 1 2}$ \\
\hline \hline Advocacy & $\checkmark$ & $\checkmark$ & $\checkmark$ & & \\
Institutional building & $\checkmark$ & & & & \\
Objectives and benefits of CP & & $\checkmark \checkmark$ & & $\checkmark$ & $\checkmark \checkmark$ \\
Scope of CP & & $\checkmark$ & $\checkmark$ & $\checkmark$ & \\
International cooperation & & $\checkmark$ & & $\checkmark$ & $\checkmark$ \\
Enforcement & & & $\checkmark$ & & $\checkmark$ \\
Roles and responsibilities of competition agency & & & & & $\checkmark$ \\
Regional core competencies & & & & &
\end{tabular}

Table 11: Location of AEGC’s Capacity Building Activities, 2008-2012

\begin{tabular}{|c|c|c|c|c|c|}
\hline Location & 2008 & 2009 & 2010 & 2011 & 2012 \\
\hline Brunei & & & $\checkmark$ & & $\checkmark$ \\
\hline Cambodia & & & $\checkmark$ & & \\
\hline Indonesia & & & & $\checkmark \checkmark$ & \\
\hline Lao PDR & & & & & $\checkmark$ \\
\hline Malaysia & & $\checkmark \checkmark$ & & & $\checkmark$ \\
\hline Myanmar & & & & & \\
\hline Philippines & & & & & \\
\hline Singapore & $\checkmark$ & $\checkmark$ & & & \\
\hline Thailand & & $\checkmark$ & & & \\
\hline Viet Nam & & $\checkmark \checkmark$ & $\checkmark$ & $\checkmark$ & $\checkmark$ \\
\hline Other Non-ASEAN countries (e.g. Japan etc.) & $\checkmark$ & & & & $\checkmark$ \\
\hline
\end{tabular}

Source: AEGC

\section{(d) Regional Guideline on Competition Policy}

The fourth action listed in the AEC Blueprint emphasized on the drafting of a regional guideline on competition policy. It was formally stated in the Blueprint as follows: "Develop a regional guideline on competition policy by 2010, based on country experiences and international best practices with the view to creating a fair competition environment.” 
The level of implementation for fourth action can be considered to be high based on the completion and publication of the document "ASEAN Regional Guidelines on Competition Policy". The Guideline was completed by AEGC and subsequently published by the ASEAN Secretariat in 2010. The primary aim of the Guideline is to provide "a general framework guide for the AMSs as they endeavour to introduce, implement and develop competition policy in accordance with the specific legal and economic context of each AMS” (ASEAN, 2010a, p.1).

The document primarily focuses on competition law. The approach taken is similar to the "Model Law" template approach published by the UNCTAD. It provides discussions of various options available in structuring competition law. The Guideline is to be used as a reference and is not binding on the AMSs. An accompanying unpublished document titled "Reference Document Annex to ASEAN Regional Guidelines on Competition Policy” provides more detailed explanation and discussions of best practices based on the experiences of a number of countries.

The Guideline recognizes a broad definition of competition policy as "governmental measures that directly affect the behavior of enterprises and the structure of industry and markets”. As mentioned earlier, despite this definition, the Guideline focuses on the competition law component of competition policy. Two reasons might account for this approach. First, the membership of AEGC comes primarily from competition agencies (for countries with competition law) or ministries responsible for domestic competition-related matters (for countries without competition law). Second, a broader definition of competition policy is likely to cover very large areas/topics including those appearing in other areas of the AEC Blueprint which may be better handled by SEOM. 
The Guideline can potentially lead to convergence of competition laws in ASEAN if its member states refer to it in their draft and revision processes. However, there has been no competition law which was adopted after the Guideline came in. Therefore, convergence is a future task.

Another issue that is indirectly raised by the Guideline is the need to carefully consider issues related to competition law at the community-level (ASEAN). This is particularly important in the context of AEC, as expressed in the Guideline:

“The Regional Guidelines endeavour to help in the process of building stronger economic integration in the region, by acting as a common reference guide for future cooperation to enhance the competitive process in the AMSs.” (ASEAN, 2010a, p. 1)

Given the differences in competition laws across AMSs, the harmonization of national competition laws to ensure consistency across AMSs may need to be discussed further in the future. The current diversity and differences in competition laws in more developed jurisdictions clearly indicates that this is a complex issue. For example, should there be converge towards an agreed standard for some elements of national competition laws such as threshold levels, sanctions and merger controls? Further down the road, should ASEAN-member countries consider the establishment of a supra-national competition agency such as the Competition Commission in the EU?

In this regard, the direction taken by AMSs is likely to be influenced by the future direction of ASEAN and the AEC. The supra-national approach may not materialize given AMSs’ past preference for avoiding the creation of supranational 
regional institution (Hill \& Menon, 2010). This implies that the cost-benefit calculus of alternative institutional arrangements is likely to go beyond economic considerations.

\section{(e) Additional Priority Actions}

Aside from the four actions on competition policy, the AEC Blueprint also provides a strategic schedule for the implementation of additional priority actions from 2008 to 2015. What follows is an evaluation of compliance to this schedule.

For the period 2008-2009, the additional priority actions listed is stated as "Carrying out a foundation-laying study, review of study findings and recommendations, and convening a regional meeting on study findings and recommendations". These priority actions have been carried out and completed in 2008. The "foundation-laying study" was undertaken in the form of the study on "Best practices in the introduction and implementation of competition policy and law” which was completed in June 2008. A regional workshop was organized to discuss findings of the Study in May 2008. The study provided important inputs into AEGC's subsequent activities in the following areas:

- Discussions on best practices in competition law which can be considered to be a precursor to the ASEAN Regional Guideline on Competition Policy.

- Recommendations on cooperative arrangement and activities by AMSs in the area of competition policy and law.

- List of activities that can be carried out by AEGC for the next five years.

- Recommendations on best practices in the design and delivery of technical assistance and capacity building programs.

For the period covering 2010 and beyond, the additional actions included in the Blueprint included the following: 
- "Drawing up a regional work plan on Competition Policy and Law with special focus: capacity building and the introduction of best practices for introducing competition policy.”

- "Exploring funding opportunities for the implementation of selected elements of the work plan in line with the strategic schedules of AEC building.”

The priority action on the regional work plan was completed in 2010 in the form of a capacity building road map. As discussed earlier, the AEGC has actively organized capacity building activities since 2008. There is clearly an urgent need to undertake a work plan for capacity building. The emerging expertise within the ASEAN grouping as well as the dearth of expertise especially in countries at the initial stage of implementation suggests that there is a dire need for such a work plan. In this regard, the AEGC has tabled a capacity building roadmap (at the regional level) at the sixth AEGC Meeting on 8-9 July 2010 in Brunei.

The priority action on the exploration of funding opportunities for the work plan has been completed partly via commitments from a number of donor agencies. To date, the funding of capacity building activities by various enforcement agencies and AEGC has been carried out on a fairly ad-hoc basis. During the period under review, the AEGC has received funding for capacity building from:

- InWEnt (now GIZ) covering the periods 2009-2010 and 2011-2013; and

- $\quad$ ASEAN-GIZ (former GTZ) for the period 2011-2014. 


\section{Conclusions and Policy Recommendations}

The AEC Blueprint, with its list of priority actions and schedules, provides an opportunity for AMSs to focus on operational aspects of achieving regional economic integration in the form of the AEC. Many of the key areas that ASEAN has focused on to achieve this objective involves the promotion of the competition process. In fact, competition is a key aspect of regional integration and competition policy is an essential instrument.

In terms of the implementation of competition policy, AMSs have made significant strides. Trade liberalization has lowered tariff levels. Initiatives are on going to reduce non-tariff barriers and other impediments to regional integration. The progress in competition law is more modest. Only five of the AMSs have implemented competition laws. Of these, a few have been successful but their experiences are very diverse. Not only are there stark differences in the competition laws across AMSs, the enforcement focus amongst these countries have varied significantly. Path dependence - where early success leads to virtuous circle provides further evidence on the importance of design and institutional capacity. ASEAN needs to learn from these experiences and consider what they imply for the future of competition policy within the AEC. Recent capacity building activities organized by AEGC have begun to look into this area.

The reviews and assessments presented in this study point to a few broad policy recommendations. The recommendations are organized into two categories, namely those implementable before 2015 and after 2015.

In the case of policy emphasis for the period up to 2015, priority should be given to addressing the problem of the implementation of competition laws in the 
remaining countries which have not done so. As a response to the current state of implementation, a renewal of commitment at the SEOM-level is required to ensure compliance to the 2015 deadline. For countries that do not have the requisite resources and institutions, future capacity-building activities should be specifically targeted towards meeting the needs of these countries.

With trade and services liberalization, cross-border intra-ASEAN competition cases are expected to become more important. Under the aegis of regional cooperation, AEGC should begin explorations of the possible arrangements for enforcement cooperation, including general information exchange, case-handling guidelines, etc. These may range from informal approaches to more formal arrangements. Past experience suggests that informal approaches involving sharing of enforcement experiences and non-confidential documents especially in mergerrelated cases can be fairly effective (Jenny, 2002). In contrast, more formal arrangements tend to be more time-consuming and often require formal treaties (bilateral, or plurilateral). In the past, formal avenues of cooperation have been incorporated in trade agreements. A road map (similar to that for capacity building) needs to be put in place to begin this process.

Due to the scarce expertise and talents, there is a need to consider pooling resources for capacity building at the ASEAN-level. Donors are increasingly interested to fund capacity-building at the regional rather than national level. New institutions and delivery mechanisms should be considered, e.g. pool of experts, and competition law and economics training programs in the region. At present, plans are already afoot to develop such a pool of experts under the ASEAN-GIZ Project on Competition Policy and Law (CPL). Training programs may be self-funded in collaboration with institutions of higher learning operating in the ASEAN region. A 
first step should be taken by identifying and negotiating with one or two reputable universities located in the countries with established track record in competition law enforcement (such as Indonesia and Singapore).

In the longer term (beyond 2015), there is a need to broaden the policy discussions and formulations to more explicitly include competition, competition policy and industrial policy as a key aspect of regional integration. The role and impact of competition policy, broadly defined, is certainly pervasive within the vision of AEC. This aspect is already recognized in some AMSs such as Indonesia where competition authorities have legal mandate to provide policy advice on competition-related matters.

In addition there is a need to consider how competition policy and law should be embedded and co-evolve with regional integration. Is there a need, for example, for greater harmonization and convergence amongst competition law regimes within ASEAN? How might EU's experience differ from ASEAN's given their different approaches to regional integration. The sequencing of the regional integration process in ASEAN will impact how competition policy at the regional level should be addressed.

A key debate in regional integration is the geographical agglomeration effects that emerge in terms of competition and location. The perception of unequal benefits from the implementation of competition policy and law needs to be examined and considered further. This is particularly important given the uneven state of development across the AMSs.

There is a need to re-evaluate the role and modus-operandi of AEGC as the key drive for competition policy/law in the AMSs. This includes a consideration of whether there is a need to go beyond the focus on "competition law as competition 
policy”. Given the current state of competition policy implementation, this is likely to be a post-2015 issue. Central to this issue is the question of how much regional centralization and coordination is needed or desirable. Related to this is the question of evolution towards a higher level of intra agency-level cooperation. This is a question pertaining to the evolution of AEC in the long-term.

Finally, the present priority action relates primarily to the introduction of competition laws. As some of the existing competition law regimes are not functioning optimally, AMSs should consider how to assist in reforming such regimes. This will definitely go beyond capacity-building exercises that are mainly of interest to newer competition regimes.

\section{References}

Aldaba, R. M. (2011), 'Trade Reforms, Competition, and Innovation in the Philippines', in Globalization and Innovation in East Asia, edited by Chin Hee Hanh and Dionisius Narjoko, ERIA Research Project Report 2010-4.

Aldaba, R. M. (2012), 'Exising competition laws and regulations in the Philippines', Draft report, Makati City: Philippine Institute for Development Studies.

ASEAN (2008), ASEAN Economic Community Blueprint. Jakarta: ASEAN Secretariat.

ASEAN (2009), ASEAN Integration in Services. Jakarta: ASEAN Secretariat.

ASEAN (2010a), ASEAN Regional Guidelines on Competition Policy. Jakarta: ASEAN Secretariat.

ASEAN (2010b), Handbook on Competition Policy and Law in ASEAN for Business. Jakarta: ASEAN Secretariat.

ASEAN (2012), ASEAN Economic Community Scorecard. Jakarta: ASEAN Secretariat. 
Aswicahyono, H. and P. Kartika (2010), 'Competition Policy in Indonesia: A Stock Take of Recent Development', (mimeo).

Brooks, D. and Evenett (eds.) (2005), Competition Policy and Development in Asia. New York: Palgrave Macmillan.

Crandall, R. and C. Winston (2003), 'Does Antitrust Policy Improve Consumer Welfare? Assessing the Evidence', Journal of Economic Perspectives, 17(4), pp.3-26.

Gal, M. S. (2003), Competition Policy for Small Market Economies. Cambridge, MA: Harvard University Press.

Gal, M. S. (2001), 'Size Does Matter: The Effects of Market Size on Optimal CompetitionPolicy', University of Southern California Law Review, 74, pp.1437-1478.

Hill, H. and J. Menon (2010), 'ASEAN Economic Integration: Features, Fulfillments, Failures and the Future', $A D B$ Working Paper Series on Regional Economic Integration, No.69, Manila: Asian Development Bank.

Jenny, F., (2002), 'International Cooperation on Competition: Myth, Reality andPerspective', (mimeo).

Jones, A. and B. Sufrin (2011), EU Competition Law: Text, Cases and Materials. Oxford: Oxford University Press.

Kohpaiboon, A. and A. Tanasritunyakul (2010), 'Competition Policy in Thailand', (mimeo).

Komisi Pengawas Persaingan Usaha (KPPU).(n.d.) Annual Report. Various Years.

Kroes, N., (2009), 'How Competition Policy Benefits SMEs', speech at the Craft and SME Convention at European Economic and Social Committee, Brussels, 27th April 2009.

Lee, C. (2005), 'Malaysia', in Competition Policy and Development in Asia, edited by D.H.Brooks and S.J.Evenett. Basingstoke: Palgrave Macmillan.

Lee, C. (2010), 'Competition and Industrial Policies in Southeast Asia’(mimeo).

Lee, C. and Y. Fukunaga. (2012), ‘AEC Mid-term Review on Competition Policy’ (mimeo). 
Lloyd, P. (2005), 'What is a Single Market? An Application to the Case of ASEAN', ASEAN Economic Bulletin 22, pp.251-65.

Mikic, M. (2009), 'ASEAN and Trade Integration', Trade and Investment, Staff Working Paper 01/09, New York: United Nations, ESCAP.

Nikomborirak, D. (2006), 'The Political Economy of Competition Law: The Case of Thailand', Northwestern Pasaribu, Benny (2011) 'Competition Policy and Economic Development', presentation at the ASEAN Competition Forum, Bali, 15-16 November 2011.

Ong, B. (2006), 'The Origins, Objectives and Structure of Competition Law in Singapore, World Competition 29, pp.269-284.

Pangestu, M., H. Aswicahyono, T. Anas and D. Ardyanto (2002), 'The Evolution of Competition Policy in Indonesia', Review of Industrial Organization, pp.205224.

Pasaribu, B. (2011), 'Competition Policy and Economic Development', presentation at the ASEAN Competition Forum, Bali, 15-16 November 2011.

Plummer, M. and S.Y. Chia (eds.) (2009), Realizing the ASEAN Economic Community: A Comprehensive Assessment. Singapore: Institute of Southeast Asian Studies.

Pupphavesa, W., S. Chaisrisawatsuk, S. Sudsawasd and S. Ongkittikul (2009), 'Competition Policy, Infrastructure and Intellectual Property Rights', in Realizing the ASEAN Economic Community: A Comprehensive Assessment, edited by M. Plummer and S.Y. Chia. Singapore: Institute of Southeast Asian Studies.

Singapore Competition Commission. Annual Report. Various Years.

Tran, A.S. (2007), 'Vietnam Experience in Establishing a Competition Regime', presentation at APEC Economic Committee II Seminar, Cairns, Queensland, 27 June.

Tran, T.Q. (2010), 'Competition Policy in Vietnam: Economic Background, Application and Prospect', Asian Development Bank, mimeo.

UNCTAD (1997), 'Empirical evidence on the benefits from applying competition law and policy principles to economic development in order to obtain greater 
efficiency in international trade and development', Report No TD/B/COM.2/EM/10, 18 September 1997.

Wattanapruttipaisan, T. (2006), ‘A Brief on ASEAN Economic Integration’, mimeo.

Wise, M. (2007), 'Competition Law and Policy in the European Union (2005)', OECD Journal of Competition Law and Policy 9, pp.7-80.

\section{ENDNOTES}

${ }^{1}$ See Plummer and Chia (2009) for an early discussion of the AEC.

${ }^{2}$ For the purpose of this study, the terms competition policy is defined in accordance to the ASEAN Regional Guidelines on Competition Policy published by the ASEAN Secretariat in 2010: “Competition policy can be broadly defined as a governmental policy that promotes or maintains the level of competition in markets, and includes governmental measures that directly affect the behaviour of enterprises and the structure of industry and markets”. (ASEAN. 2010a, p.3).

3 This study is developed from the authors' unpublished paper, namely Lee and Fukunaga (2012).

${ }^{4}$ Note that firms in a country are unlikely to be competitive internationally without being competitive in the domestic market due to lack of incentives to be efficient and innovative. Such firms can still compete internationally if it enjoys protection or/and subsidies in their home markets but at significant costs to consumers and tax payers in the home country.

${ }^{5}$ ASEAN (2008), p.6.

6 The emphasis on such freedoms may be a question of degree compared to the theoretical ideal. For example, in the case of capital movement, the emphasis in the AEC Blueprint is on "freer flow" of capital rather than "free” movement of capital.

7 ASEAN (2010a), p.3.

${ }^{8}$ See Lee (2010) for a more detailed discussion.

${ }^{9}$ For more details see ASEAN (2012).

10 For an early discussion of differences in the competition laws of Indonesia, Singapore, Thailand and Vietnam see Pupphavesa, et al. (2009).

${ }^{11}$ Community dimensions refer to cases involving large firms with significant presence across a number of EU countries.

12 The following discussions rely on Nikomborirak (2006) and Kohpaiboon \& Tanasritunyakul (2010).

13 ASEAN (2010a), p.3. 


\section{ERIA Discussion Paper Series}

\begin{tabular}{|c|c|c|c|}
\hline No. & Author(s) & Title & Year \\
\hline 2013-03 & $\begin{array}{l}\text { Cassey LEE and Yoshifumi } \\
\text { FUKUNAGA }\end{array}$ & ASEAN Regional Cooperation on Competition Policy & $\begin{array}{c}\text { Apr } \\
2013\end{array}$ \\
\hline 2013-02 & $\begin{array}{l}\text { Yoshifumi FUKUNAGA } \\
\text { and Ikumo ISONO }\end{array}$ & $\begin{array}{l}\text { Taking ASEAN+1 FTAs towards the RCEP: } \\
\text { A Mapping Study }\end{array}$ & $\begin{array}{c}\text { Jan } \\
2013\end{array}$ \\
\hline 2013-01 & Ken ITAKURA & $\begin{array}{l}\text { Impact of Liberalization and Improved Connectivity } \\
\text { and Facilitation in ASEAN for the ASEAN Economic } \\
\text { Community }\end{array}$ & $\begin{array}{c}\text { Jan } \\
2013\end{array}$ \\
\hline $2012-17$ & $\begin{array}{l}\text { Sun XUEGONG, Guo } \\
\text { LIYAN, Zeng ZHENG }\end{array}$ & $\begin{array}{l}\text { Market Entry Barriers for FDI and Private Investors: } \\
\text { Lessons from China's Electricity Market }\end{array}$ & $\begin{array}{l}\text { Aug } \\
2012\end{array}$ \\
\hline $2012-16$ & Yanrui WU & $\begin{array}{l}\text { Electricity Market Integration: Global Trends and } \\
\text { Implications for the EAS Region }\end{array}$ & $\begin{array}{l}\text { Aug } \\
2012\end{array}$ \\
\hline $2012-15$ & $\begin{array}{l}\text { Youngho CHANG, Yanfei } \\
\text { LI }\end{array}$ & $\begin{array}{l}\text { Power Generation and Cross-border Grid Planning for } \\
\text { the Integrated ASEAN Electricity Market: A Dynamic } \\
\text { Linear Programming Model }\end{array}$ & $\begin{array}{l}\text { Aug } \\
2012\end{array}$ \\
\hline $2012-14$ & Yanrui WU, Xunpeng SHI & $\begin{array}{l}\text { Economic Development, Energy Market Integration and } \\
\text { Energy Demand: Implications for East Asia }\end{array}$ & $\begin{array}{l}\text { Aug } \\
2012\end{array}$ \\
\hline $2012-13$ & $\begin{array}{l}\text { Joshua AIZENMAN, } \\
\text { Minsoo LEE, and } \\
\text { Donghyun PARK }\end{array}$ & $\begin{array}{l}\text { The Relationship between Structural Change and } \\
\text { Inequality: } \\
\text { A Conceptual Overview with Special Reference to } \\
\text { Developing Asia }\end{array}$ & $\begin{array}{c}\text { July } \\
2012\end{array}$ \\
\hline $2012-12$ & $\begin{array}{l}\text { Hyun-Hoon LEE, Minsoo } \\
\text { LEE, and Donghyun PARK }\end{array}$ & $\begin{array}{l}\text { Growth Policy and Inequality in Developing Asia: } \\
\text { Lessons from Korea }\end{array}$ & $\begin{array}{l}\text { July } \\
2012\end{array}$ \\
\hline $2012-11$ & Cassey LEE & $\begin{array}{l}\text { Knowledge Flows, Organization and Innovation: } \\
\text { Firm-Level Evidence from Malaysia }\end{array}$ & $\begin{array}{l}\text { June } \\
2012\end{array}$ \\
\hline $2012-10$ & $\begin{array}{l}\text { Jacques MAIRESSE, Pierre } \\
\text { MOHNEN, Yayun ZHAO, } \\
\text { and Feng ZHEN }\end{array}$ & $\begin{array}{l}\text { Globalization, Innovation and Productivity in } \\
\text { Manufacturing Firms: A Study of Four Sectors of China }\end{array}$ & $\begin{array}{l}\text { June } \\
2012\end{array}$ \\
\hline 2012-09 & Ari KUNCORO & $\begin{array}{l}\text { Globalization and Innovation in Indonesia: Evidence } \\
\text { from Micro-Data on Medium and Large Manufacturing } \\
\text { Establishments }\end{array}$ & $\begin{array}{l}\text { June } \\
2012\end{array}$ \\
\hline
\end{tabular}




\begin{tabular}{|c|c|c|c|}
\hline No. & Author(s) & Title & Year \\
\hline 2012-08 & Alfons PALANGKARAYA & $\begin{array}{l}\text { The Link between Innovation and Export: Evidence } \\
\text { from Australia's Small and Medium Enterprises }\end{array}$ & $\begin{array}{l}\text { June } \\
2012\end{array}$ \\
\hline 2012-07 & $\begin{array}{l}\text { Chin Hee HAHN and } \\
\text { Chang-Gyun PARK }\end{array}$ & $\begin{array}{l}\text { Direction of Causality in Innovation-Exporting Linkage: } \\
\text { Evidence on Korean Manufacturing }\end{array}$ & $\begin{array}{l}\text { June } \\
2012\end{array}$ \\
\hline 2012-06 & Keiko ITO & $\begin{array}{l}\text { Source of Learning-by-Exporting Effects: Does } \\
\text { Exporting Promote Innovation? }\end{array}$ & $\begin{array}{l}\text { June } \\
2012\end{array}$ \\
\hline 2012-05 & Rafaelita M. ALDABA & $\begin{array}{l}\text { Trade Reforms, Competition, and Innovation in the } \\
\text { Philippines }\end{array}$ & $\begin{array}{l}\text { June } \\
2012\end{array}$ \\
\hline 2012-04 & $\begin{array}{l}\text { Toshiyuki MATSUURA } \\
\text { and Kazunobu } \\
\text { HAYAKAWA }\end{array}$ & $\begin{array}{l}\text { The Role of Trade Costs in FDI Strategy of } \\
\text { Heterogeneous Firms: Evidence from Japanese } \\
\text { Firm-level Data }\end{array}$ & $\begin{array}{l}\text { June } \\
2012\end{array}$ \\
\hline $2012-03$ & $\begin{array}{l}\text { Kazunobu HAYAKAWA, } \\
\text { Fukunari KIMURA, and } \\
\text { Hyun-Hoon LEE }\end{array}$ & $\begin{array}{l}\text { How Does Country Risk Matter for Foreign Direct } \\
\text { Investment? }\end{array}$ & $\begin{array}{l}\text { Feb } \\
2012\end{array}$ \\
\hline 2012-02 & $\begin{array}{l}\text { Ikumo ISONO, Satoru } \\
\text { KUMAGAI, Fukunari } \\
\text { KIMURA }\end{array}$ & $\begin{array}{l}\text { Agglomeration and Dispersion in China and ASEAN: } \\
\text { A Geographical Simulation Analysis }\end{array}$ & $\begin{array}{c}\text { Jan } \\
2012\end{array}$ \\
\hline $2012-01$ & $\begin{array}{l}\text { Mitsuyo ANDO } \\
\text { and Fukunari KIMURA }\end{array}$ & $\begin{array}{l}\text { How Did the Japanese Exports Respond to Two Crises } \\
\text { in the International Production Network?: } \\
\text { The Global Financial Crisis and the East Japan } \\
\text { Earthquake }\end{array}$ & $\begin{array}{c}\text { Jan } \\
2012\end{array}$ \\
\hline $2011-10$ & $\begin{array}{l}\text { Tomohiro MACHIKITA } \\
\text { and Yasushi UEKI }\end{array}$ & $\begin{array}{l}\text { Interactive Learning-driven Innovation in } \\
\text { Upstream-Downstream Relations: } \\
\text { Evidence from Mutual Exchanges of Engineers in } \\
\text { Developing Economies }\end{array}$ & $\begin{array}{l}\text { Dec } \\
2011\end{array}$ \\
\hline 2011-09 & $\begin{array}{l}\text { Joseph D. ALBA, Wai-Mun } \\
\text { CHIA, and Donghyun } \\
\text { PARK }\end{array}$ & $\begin{array}{l}\text { Foreign Output Shocks and Monetary Policy Regimes } \\
\text { in Small Open Economies: } \\
\text { A DSGE Evaluation of East Asia }\end{array}$ & $\begin{array}{l}\text { Dec } \\
2011\end{array}$ \\
\hline 2011-08 & $\begin{array}{l}\text { Tomohiro MACHIKITA } \\
\text { and Yasushi UEKI }\end{array}$ & $\begin{array}{l}\text { Impacts of Incoming Knowledge on Product Innovation: } \\
\text { Econometric Case Studies of Technology Transfer of } \\
\text { Auto-related Industries in Developing Economies }\end{array}$ & $\begin{array}{l}\text { Nov } \\
2011\end{array}$ \\
\hline 2011-07 & Yanrui WU & $\begin{array}{l}\text { Gas Market Integration: } \\
\text { Global Trends and Implications for the EAS Region }\end{array}$ & $\begin{array}{l}\text { Nov } \\
2011\end{array}$ \\
\hline 2011-06 & Philip Andrews-SPEED & $\begin{array}{l}\text { Energy Market Integration in East Asia: } \\
\text { A Regional Public Goods Approach }\end{array}$ & $\begin{array}{l}\text { Nov } \\
2011\end{array}$ \\
\hline 2011-05 & Yu SHENG, & $\begin{array}{l}\text { Energy Market Integration and Economic } \\
\text { Convergence: }\end{array}$ & Oct \\
\hline
\end{tabular}




\begin{tabular}{|c|c|c|c|}
\hline No. & Author(s) & Title & Year \\
\hline & Xunpeng SHI & Implications for East Asia & 2011 \\
\hline 2011-04 & $\begin{array}{l}\text { Sang-Hyop LEE, Andrew } \\
\text { MASON, and Donghyun } \\
\text { PARK }\end{array}$ & $\begin{array}{l}\text { Why Does Population Aging Matter So Much for } \\
\text { Asia? } \\
\text { Population Aging, Economic Security and } \\
\text { Economic Growth in Asia }\end{array}$ & $\begin{array}{l}\text { Aug } \\
2011\end{array}$ \\
\hline 2011-03 & $\begin{array}{l}\text { Xunpeng SHI, } \\
\text { Shinichi GOTO }\end{array}$ & $\begin{array}{l}\text { Harmonizing Biodiesel Fuel Standards in East Asia: } \\
\text { Current Status, Challenges and the Way Forward }\end{array}$ & $\begin{array}{l}\text { May } \\
2011\end{array}$ \\
\hline 2011-02 & Hikari ISHIDO & $\begin{array}{l}\text { Liberalization of Trade in Services under ASEAN }+n \text { : } \\
\text { A Mapping Exercise }\end{array}$ & $\begin{array}{l}\text { May } \\
2011\end{array}$ \\
\hline 2011-01 & $\begin{array}{l}\text { Kuo-I CHANG, } \\
\text { Kazunobu HAYAKAWA } \\
\text { Toshiyuki MATSUURA }\end{array}$ & $\begin{array}{l}\text { Location Choice of Multinational Enterprises in } \\
\text { China: Comparison between Japan and Taiwan }\end{array}$ & $\begin{array}{l}\text { Mar } \\
2011\end{array}$ \\
\hline $2010-11$ & $\begin{array}{l}\text { Charles HARVIE, } \\
\text { Dionisius NARJOKO, } \\
\text { Sothea OUM }\end{array}$ & $\begin{array}{l}\text { Firm Characteristic Determinants of SME } \\
\text { Participation in Production Networks }\end{array}$ & $\begin{array}{c}\text { Oct } \\
2010\end{array}$ \\
\hline $2010-10$ & Mitsuyo ANDO & $\begin{array}{l}\text { Machinery Trade in East Asia, and the Global } \\
\text { Financial Crisis }\end{array}$ & $\begin{array}{l}\text { Oct } \\
2010\end{array}$ \\
\hline 2010-09 & $\begin{array}{l}\text { Fukunari KIMURA } \\
\text { Ayako OBASHI }\end{array}$ & $\begin{array}{l}\text { International Production Networks in Machinery } \\
\text { Industries: Structure and Its Evolution }\end{array}$ & $\begin{array}{c}\text { Sep } \\
2010\end{array}$ \\
\hline $2010-08$ & $\begin{array}{l}\text { Tomohiro MACHIKITA, } \\
\text { Shoichi MIYAHARA, } \\
\text { Masatsugu TSUJI, and } \\
\text { Yasushi UEKI }\end{array}$ & $\begin{array}{l}\text { Detecting Effective Knowledge Sources in Product } \\
\text { Innovation: Evidence from Local Firms and } \\
\text { MNCs/JVs in Southeast Asia }\end{array}$ & $\begin{array}{l}\text { Aug } \\
2010\end{array}$ \\
\hline 2010-07 & $\begin{array}{l}\text { Tomohiro MACHIKITA, } \\
\text { Masatsugu TSUJI, and } \\
\text { Yasushi UEKI }\end{array}$ & $\begin{array}{l}\text { How ICTs Raise Manufacturing Performance: } \\
\text { Firm-level Evidence in Southeast Asia }\end{array}$ & $\begin{array}{l}\text { Aug } \\
2010\end{array}$ \\
\hline 2010-06 & Xunpeng SHI & $\begin{array}{l}\text { Carbon Footprint Labeling Activities in the East Asia } \\
\text { Summit Region: Spillover Effects to Less Developed } \\
\text { Countries }\end{array}$ & $\begin{array}{l}\text { July } \\
2010\end{array}$ \\
\hline $2010-05$ & $\begin{array}{l}\text { Kazunobu HAYAKAWA, } \\
\text { Fukunari KIMURA, and } \\
\text { Tomohiro MACHIKITA }\end{array}$ & $\begin{array}{l}\text { Firm-level Analysis of Globalization: A Survey of the } \\
\text { Eight Literatures }\end{array}$ & $\begin{array}{l}\text { Mar } \\
2010\end{array}$ \\
\hline 2010-04 & $\begin{array}{l}\text { Tomohiro MACHIKITA } \\
\text { and Yasushi UEKI }\end{array}$ & $\begin{array}{l}\text { The Impacts of Face-to-face and Frequent } \\
\text { Interactions on Innovation: } \\
\text { Upstream-Downstream Relations }\end{array}$ & $\begin{array}{l}\text { Feb } \\
2010\end{array}$ \\
\hline
\end{tabular}




\begin{tabular}{|c|c|c|c|}
\hline No. & Author(s) & Title & Year \\
\hline $2010-03$ & $\begin{array}{l}\text { Tomohiro MACHIKITA } \\
\text { and Yasushi UEKI }\end{array}$ & $\begin{array}{l}\text { Innovation in Linked and Non-linked Firms: } \\
\text { Effects of Variety of Linkages in East Asia }\end{array}$ & $\begin{array}{c}\mathrm{Feb} \\
2010\end{array}$ \\
\hline $2010-02$ & $\begin{array}{l}\text { Tomohiro MACHIKITA } \\
\text { and Yasushi UEKI }\end{array}$ & $\begin{array}{l}\text { Search-theoretic Approach to Securing New } \\
\text { Suppliers: Impacts of Geographic Proximity for } \\
\text { Importer and Non-importer }\end{array}$ & $\begin{array}{l}\text { Feb } \\
2010\end{array}$ \\
\hline $2010-01$ & $\begin{array}{l}\text { Tomohiro MACHIKITA } \\
\text { and Yasushi UEKI }\end{array}$ & $\begin{array}{l}\text { Spatial Architecture of the Production Networks in } \\
\text { Southeast Asia: } \\
\text { Empirical Evidence from Firm-level Data }\end{array}$ & $\begin{array}{c}\text { Feb } \\
2010\end{array}$ \\
\hline $2009-23$ & Dionisius NARJOKO & $\begin{array}{l}\text { Foreign Presence Spillovers and Firms' Export } \\
\text { Response: } \\
\text { Evidence from the Indonesian Manufacturing }\end{array}$ & $\begin{array}{l}\text { Nov } \\
2009\end{array}$ \\
\hline $2009-22$ & $\begin{array}{l}\text { Kazunobu HAYAKAWA, } \\
\text { Daisuke HIRATSUKA, } \\
\text { Kohei SHIINO, and } \\
\text { Seiya SUKEGAWA }\end{array}$ & Who Uses Free Trade Agreements? & $\begin{array}{l}\text { Nov } \\
2009\end{array}$ \\
\hline $2009-21$ & Ayako OBASHI & $\begin{array}{l}\text { Resiliency of Production Networks in Asia: } \\
\text { Evidence from the Asian Crisis }\end{array}$ & $\begin{array}{c}\text { Oct } \\
2009\end{array}$ \\
\hline $2009-20$ & $\begin{array}{l}\text { Mitsuyo ANDO and } \\
\text { Fukunari KIMURA }\end{array}$ & Fragmentation in East Asia: Further Evidence & $\begin{array}{c}\text { Oct } \\
2009\end{array}$ \\
\hline $2009-19$ & Xunpeng SHI & $\begin{array}{l}\text { The Prospects for Coal: } \\
\text { Global Experience and Implications for Energy } \\
\text { Policy }\end{array}$ & $\begin{array}{l}\text { Sept } \\
2009\end{array}$ \\
\hline $2009-18$ & Sothea OUM & $\begin{array}{l}\text { Income Distribution and Poverty in a CGE } \\
\text { Framework: A Proposed Methodology }\end{array}$ & $\begin{array}{c}\text { Jun } \\
2009\end{array}$ \\
\hline $2009-17$ & $\begin{array}{l}\text { Erlinda M. MEDALLA } \\
\text { and Jenny BALBOA }\end{array}$ & $\begin{array}{l}\text { ASEAN Rules of Origin: } \\
\text { Lessons and Recommendations for the Best Practice }\end{array}$ & $\begin{array}{c}\text { Jun } \\
2009\end{array}$ \\
\hline $2009-16$ & Masami ISHIDA & Special Economic Zones and Economic Corridors & $\begin{array}{c}\text { Jun } \\
2009\end{array}$ \\
\hline $2009-15$ & Toshihiro KUDO & $\begin{array}{l}\text { Border Area Development in the GMS: } \\
\text { Turning the Periphery into the Center of Growth }\end{array}$ & $\begin{array}{l}\text { May } \\
2009\end{array}$ \\
\hline $2009-14$ & $\begin{array}{l}\text { Claire HOLLWEG and } \\
\text { Marn-Heong WONG }\end{array}$ & $\begin{array}{l}\text { Measuring Regulatory Restrictions in Logistics } \\
\text { Services }\end{array}$ & $\begin{array}{c}\text { Apr } \\
2009\end{array}$ \\
\hline $2009-13$ & Loreli C. De DIOS & Business View on Trade Facilitation & $\begin{array}{l}\text { Apr } \\
2009\end{array}$ \\
\hline
\end{tabular}




\begin{tabular}{|c|c|c|c|}
\hline No. & Author(s) & Title & Year \\
\hline $2009-12$ & $\begin{array}{l}\text { Patricia SOURDIN and } \\
\text { Richard POMFRET }\end{array}$ & Monitoring Trade Costs in Southeast Asia & $\begin{array}{c}\text { Apr } \\
2009\end{array}$ \\
\hline $2009-11$ & $\begin{array}{l}\text { Philippa DEE and } \\
\text { Huong DINH }\end{array}$ & $\begin{array}{l}\text { Barriers to Trade in Health and Financial Services in } \\
\text { ASEAN }\end{array}$ & $\begin{array}{c}\text { Apr } \\
2009\end{array}$ \\
\hline $2009-10$ & Sayuri SHIRAI & $\begin{array}{l}\text { The Impact of the US Subprime Mortgage Crisis on } \\
\text { the World and East Asia: Through Analyses of } \\
\text { Cross-border Capital Movements }\end{array}$ & $\begin{array}{c}\text { Apr2 } \\
009\end{array}$ \\
\hline 2009-09 & $\begin{array}{l}\text { Mitsuyo ANDO } \square \text { and } \\
\text { Akie IRIYAMA }\end{array}$ & $\begin{array}{l}\text { International Production Networks and Export/Import } \\
\text { Responsiveness to Exchange Rates: } \\
\text { The Case of Japanese Manufacturing Firms }\end{array}$ & $\begin{array}{l}\text { Mar } \\
2009\end{array}$ \\
\hline $2009-08$ & $\begin{array}{l}\text { Archanun } \\
\text { KOHPAIBOON }\end{array}$ & $\begin{array}{l}\text { Vertical and Horizontal FDI Technology } \\
\text { Spillovers:Evidence from Thai Manufacturing }\end{array}$ & $\begin{array}{l}\text { Mar } \\
2009\end{array}$ \\
\hline 2009-07 & $\begin{array}{l}\text { Kazunobu HAYAKAWA, } \\
\text { Fukunari KIMURA, and } \\
\text { Toshiyuki MATSUURA }\end{array}$ & $\begin{array}{l}\text { Gains from Fragmentation at the Firm Level: } \\
\text { Evidence from Japanese Multinationals in East Asia }\end{array}$ & $\begin{array}{l}\text { Mar } \\
2009\end{array}$ \\
\hline 2009-06 & Dionisius A. NARJOKO & $\begin{array}{l}\text { Plant Entry in a More } \\
\text { LiberalisedIndustrialisationProcess: An Experience } \\
\text { of Indonesian Manufacturing during the 1990s }\end{array}$ & $\begin{array}{l}\text { Mar } \\
2009\end{array}$ \\
\hline $2009-05$ & $\begin{array}{l}\text { Kazunobu HAYAKAWA, } \\
\text { Fukunari KIMURA, and } \\
\text { Tomohiro MACHIKITA }\end{array}$ & Firm-level Analysis of Globalization: A Survey & $\begin{array}{l}\text { Mar } \\
2009\end{array}$ \\
\hline 2009-04 & $\begin{array}{l}\text { Chin Hee HAHN and } \\
\text { Chang-Gyun PARK }\end{array}$ & $\begin{array}{l}\text { Learning-by-exporting in Korean Manufacturing: } \\
\text { A Plant-level Analysis }\end{array}$ & $\begin{array}{l}\text { Mar } \\
2009\end{array}$ \\
\hline $2009-03$ & Ayako OBASHI & $\begin{array}{l}\text { Stability of Production Networks in East Asia: } \\
\text { Duration and Survival of Trade }\end{array}$ & $\begin{array}{l}\text { Mar } \\
2009\end{array}$ \\
\hline 2009-02 & Fukunari KIMURA & $\begin{array}{l}\text { The Spatial Structure of Production/Distribution } \\
\text { Networks and Its Implication for Technology } \\
\text { Transfers and Spillovers }\end{array}$ & $\begin{array}{l}\text { Mar } \\
2009\end{array}$ \\
\hline 2009-01 & $\begin{array}{l}\text { Fukunari KIMURA and } \\
\text { Ayako OBASHI }\end{array}$ & $\begin{array}{l}\text { International Production Networks: } \\
\text { Comparison between China and ASEAN }\end{array}$ & $\begin{array}{c}\text { Jan2 } \\
009\end{array}$ \\
\hline $2008-03$ & $\begin{array}{l}\text { Kazunobu HAYAKAWA } \\
\text { and Fukunari KIMURA }\end{array}$ & $\begin{array}{l}\text { The Effect of Exchange Rate Volatility on } \\
\text { International Trade in East Asia }\end{array}$ & $\begin{array}{c}\text { Dec2 } \\
008\end{array}$ \\
\hline $2008-02$ & $\begin{array}{l}\text { Satoru KUMAGAI, } \\
\text { Toshitaka GOKAN, } \\
\text { Ikumo ISONO, and }\end{array}$ & $\begin{array}{l}\text { Predicting Long-Term Effects of Infrastructure } \\
\text { Development Projects in Continental South East } \\
\text { Asia: IDE Geographical Simulation Model }\end{array}$ & $\begin{array}{c}\text { Dec2 } \\
008\end{array}$ \\
\hline
\end{tabular}


No.

Author(s)

Title

Year

Souknilanh KEOLA

Kazunobu HAYAKAWA,

2008-01 Fukunari KIMURA, and

Firm-level Analysis of Globalization: A Survey

Dec2

Tomohiro MACHIKITA

008 